\title{
Pectolinarigenin Suppresses the Tumor Growth in Nasopharyngeal Carcinoma
}

\author{
Chengyu Wang Yin Cheng Hongyi Liu Yaping Xu Hu Peng Juntian Lang \\ Jianchun Liao Haibin Liu Huanhai Liu Jingping Fan
}

Department of Otolaryngology, Changzheng Hospital, Second Military Medical University, Shanghai, China

\section{Key Words}

Pectolinarigenin $•$ Nasopharyngeal carcinoma $•$ Cell apoptosis $•$ Cell proliferation

\begin{abstract}
Background/Aims: Nasopharyngeal cancer (NPC) is one of the common human malignant diseases all over the world, and chemotherapy remains the main therapy for NPC. However, the survival and life quality of NPC patients are still very poor. Thus, novel and selective antitumor agents are pressingly needed. Our previous study identified pectolinarigenin as a novel effective anti-tumor drug candidate for NPC. In this study, we further investigated its antitumor activities and explored the potential molecular mechanism. Methods: NPC C666-1 cells were cultured and treated by pectolinarigenin. Cell proliferation assay, colony formation assay, Transwell assay and wound healing assay were conducted and cell apoptosis was detected by flow cytometry. Mitochondrial transmembrane potential and ROS were also observed. NPC subcutaneous xenograft mice model was established to evaluate the anti-tumor effect of pectolinarigenin in vivo. Results: We observed that treatment of pectolinarigenin inhibited cell viability and cell migration of NPC C666-1 cells in concentration- and time-dependent manner. Pectolinarigenin induced cell apoptosis in C666-1 cells detected by flow cytometry analysis, which was associated with the activation of mitochondrial-related apoptosis and the accumulation of reactive oxygen species (ROS). Pectolinarigenin also activated caspase signaling pathway. The in vivo experiment of subcutaneous xenograft mice model also indicated that the administration of pectolinarigenin could decrease the tumor growth of NPC and no severe toxicity was observed. Conclusions: Based on our findings, we conclude that pectolinarigenin could suppress the tumor growth of NPC, which verifies it as a new therapeutic agent for treating this devastating disease.
\end{abstract}




\section{Cellular Physiology Cell Physiol Biochem 2016;39:1795-1803

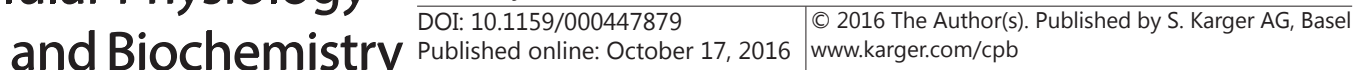 \\ Wang et al.: Anti-Tumor Effect of Pectolinarigenin in Nasopharyngeal Carcinoma}

\section{Introduction}

Nasopharyngeal carcinoma (NPC) is a characteristic tumor displaying epidemiological, genetic and regional distribution properties and is unique by its natural behavior and therapy. Although radiotherapy can achieve a high cure rate in early stage NPC, the treatment outcome for the advanced stage is still unsatisfactory [1]. Local recurrences and high frequency for distant metastasis constitute two major causes of treatment failure in NPC after radiotherapy treatment [2].

Apoptosis is a process that plays an important role in the control of the growth and development of organisms, and apoptosis induction is considered to be a crucial strategy for cancer prevention and treatment [3]. Because apoptosis induction appears to be the most important property for candidate anticancer drug, the morphological observation was conducted to explore whether the cytotoxic effect was related with the apoptotic process [4-6]. Elevation of oxidative stress species (ROS) in excess of the buffering capacity designed to modulate ROS levels result in potentially cytotoxic effect [7]. ROS and oxidative stress are known as apoptosis triggers and modulators [8], and they have been shown to participate in the therapeutic actions of multiple chemotherapeutics. Recent studies have reported that pectolinarigenin is an active component of the medicinal plant thistle division Chromolaena odorata, which exerts a significant cytotoxic activity by inducing cell apoptosis [9-11]. Thistle division has wide range of significant clinical effective applications in clinical medicine, a commonly used for hemostatic effect. Furthermore, it has shown promise in the treatment of human malignancies and has attracted great attention as a candidate compound for cancer chemotherapy [12]. Pectolinarigenin exhibits apoptotic activity, but the molecular mechanism of its apoptotic activity has not yet been completely understood.

In the present study, we further studied the anti-tumor activity of pectolinarigenin for NPC. Both in vitro and in vivo experiments showed that pectolinarigenin could reduce the growth and apoptosis of NPC C666-1 cells. These observations suggest that pectolinarigenin may be an effective chemotherapeutic agent against NPC. Further studies were performed to elucidate the underlying mechanism for inhibiting cell viability and promoting cell apoptosis. Our studies found that pectolinarigenin could trigger the mitochondrial-related apoptosis, accompanying the accumulation of ROS.

\section{Materials and Methods}

\section{Cell line and chemicals}

NPC C666-1 cell line was purchased from the cell bank of Xiangya Central Laboratory (Central South University, Changsha, China). C666-1 cells were grown in Roswell Park Memorial Institute medium (RPMI) 1640 with $12 \%$ FBS and $1 \%$ Penicillin/Streptmycin and maintained in a humidified $37^{\circ} \mathrm{C}$ incubator with $5 \% \mathrm{CO}_{2}$. Pectolinarigenin was isolated from the medicinal plant thistle division Chromolaena odorata and its structural formula was shown in Fig. 1. Pectolinaringenin used in this study was purchased from the biotechnology company of Tuoran (product code: GR1003). It was dissolved in DMSO and stored at $-20^{\circ} \mathrm{C}$, until used. The isolation procedure was as previous published [13].

\section{Cell proliferation assay and colony formation assay}

Cell growth was determined using a Cell Counting Kit-8 (CCK-8) assay (Dojindo, Kumamoto, Japan). The cells were plated into 96 -well plates at $4 \times 10^{4}$ cells $/ \mathrm{ml}$ and then treated with the indicated concentrations of pectolinarigenin for 24 and $48 \mathrm{~h}$. As a control group, DMSO was added instead (final concentration of $0.1 \%$ ). The absorbance was recorded at $450 \mathrm{~nm}$ with a microplate reader (Thermo, USA). Viability was determined when compared with DMSO group. Experiments were performed in triplicate. In colony formation assay, C666-1 cells were seeded in a 6-well plate in the amount of 1000 cells per dish for $24 \mathrm{~h}$. The cells treated with pectolinarigenin in various concentrations were incubated in $2 \mathrm{ml}$ of RPMI 1640 supplemented with $5 \%$ FBS and were incubated at $37^{\circ} \mathrm{C}$ and $5 \% \mathrm{CO}_{2}$ for 7 days. At the end of the incubation, the media were removed and colonies were washed with PBS. The colonies were fixed in $1 \mathrm{ml}$ of 


\section{Cellular Physiology Cell Physiol Biochem 2016;39:1795-1803

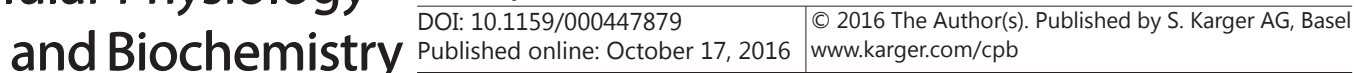 \\ Wang et al.: Anti-Tumor Effect of Pectolinarigenin in Nasopharyngeal Carcinoma}

methanol for $30 \mathrm{~min}$ and stained with $0.4 \%$ crystal violet for $20 \mathrm{~min}$ at room temperature. The numbers of colonies that contained more than 50 cells were counted and averaged.

\section{Cell apoptosis assay}

The percentage of apoptotic cells was measu-

Fig. 1. Structure of pectolinarigenin.

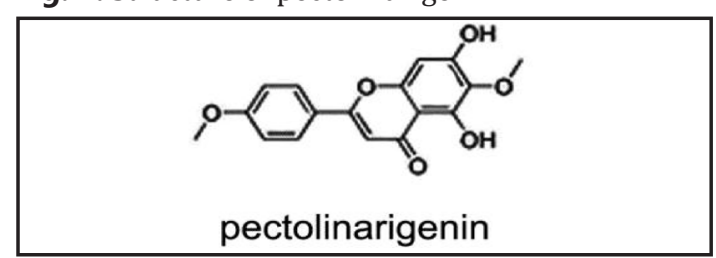
red using an Annexin V-FITC apoptosis detection kit (Thermo, USA) according to the manufacturer's protocol. The cells $\left(5 \times 10^{5}\right)$ were cultured in six-well plates and were grown to $70 \%$ confluence. After treatment with pectolinarigenin for $24 \mathrm{~h}$, the cells were harvested and washed twice with PBS, and then collected and resuspended in $500 \mathrm{ul}$ binding buffer containing $5 \mathrm{ul}$ Annexin V-FITC at a concentration of $10^{6} / \mathrm{ml}$ cells. After cells were mixed and incubated away from light for 10-15 min at room temperature, the cells were centrifuged and resuspended again in $300 \mathrm{ul}$ binding buffer containing $5 \mathrm{ul}$ PI. The stained cells were then analyzed using a flow cytometer.

\section{Measurement of mitochondrial transmembrane potential}

To investigate the mitochondrial apoptotic events involved in pectolinarigenin induced apoptosis, we tested the changes of the mitochondrial membrane potential $(\Delta \Psi \mathrm{m})$. Change of mitochondrial membrane potential was examined by fluorescent lipophilic cationic probe JC-1. The dye underwent a reversible change in fluorescence emission from red to green as $\Delta \Psi$ m decreases. Cells with high membrane potential promoted the formation of dye aggregates (red fluorescence), and cells with low membrane potential contained monomeric JC-1 (green fluorescence). After treatment with pectolinarigenin for $24 \mathrm{~h}$, the treated cells were harvested and washed with PBS. Then, samples containing $10^{6}$ cells $/ \mathrm{ml}$ were stained with prepared JC-1 solution containing $5 \mathrm{ul} \mathrm{JC}-1$ (200*), $800 \mathrm{ul}$ water and $200 \mathrm{ul} \mathrm{JC}-1$ (5*) binding buffer for $30 \mathrm{~min}$ at $37^{\circ} \mathrm{C}$. The cells were washed and resuspended in $500 \mathrm{ul}$ PBS, and fluorescence was monitored at wavelengths of 490 (excitation)/540 $\mathrm{nm}$ (emission) and 540 (excitation)/590 $\mathrm{nm}$ (emission) pairs. Changes in the ratio between 590 (red) and $540 \mathrm{~nm}$ (green) fluorescence intensities were an indicator of the mitochondrial membrane potential.

\section{Measurement of ROS generation}

Intracellular ROS production was assessed using the peroxide-sensitive fluorescent probe 20, 70-dichlorofluorescin diacetate (DCFH/DA). In brief, the cells were incubated in the presence of treatment with pectolinarigenin or DMSO for $24 \mathrm{~h}$. Then, the cells were harvested and treated with $1 \mathrm{mM}$ of DCFH-DA at $37^{\circ} \mathrm{C}$ for $30 \mathrm{~min}$. After treatment with DCFH-DA, the cells were washed with PBS twice and resuspended in PBS for detection of ROS accumulation using the FACS Caliber flow cytometry system. The relative intensity of DCF fluorescence was determined at a wavelength pair of 488/538 nm when compared with control group.

Transwell assay and wound healing assay

Transwell assay was performed in transwell cell culture chamber inserts (Corning, USA) with an 8 - $\mu \mathrm{m}$ pore size. A total of $1 \times 10^{4}$ cells that had been treated with pectolinarigenin for $24 \mathrm{~h}$ were seeded into transwell filter membrane chambers with $100 \mu \mathrm{l}$ RPMI 1640 supplemented with 1\% FBS, and 600 $\mu$ l RPMI 1640 supplemented with 20\% FBS was added to the lower compartment as a chemoattractant. After transwell chambers were incubated for $20 \mathrm{~h}$ at $37^{\circ} \mathrm{C}$ in a humidified $5 \% \mathrm{CO}_{2}$ atmosphere, the cells on the upper surfaces of the wells that migrated to the lower chamber were fixed in cold methanol for $10 \mathrm{~min}$ and were stained with $0.4 \%$ crystal violet for $10 \mathrm{~min}$ at room temperature. Excess stain was removed using physiological saline and the chambers were air-dried. For each experiment, five fields on the undersides of the membranes were randomly selected for photography and the transmigrated cells were counted and averaged. In wound healing assay, C666-1 cells treated with pectolinarigenin for $24 \mathrm{~h}$ were seeded in a 6-well plate to achieve 90\%-95\% confluency. Scratches were gently made on the monolayer using a sterile $200 \mu \mathrm{l}$ pipet tip. The cells were rinsed with fresh medium to remove any free-floating cells and debris. Photographs were taken immediately and wound healing was observed at different time points within the scrape line, and representative scrape lines were photographed. The wound area was measured using the Adobe Photoshop software. 


\section{Cellular Physiology Cell Physiol Biochem 2016;39:1795-1803 \begin{tabular}{l|l|l|} 
and Biochemistry 10.1159/000447879 & $\begin{array}{l}\text { C) 2016 The Author(s). Published by S. Karger AG, Basel } \\
\text { www.karger.com/cpb }\end{array}$ \\
\hline Published online: October 17, 2016
\end{tabular} \\ Wang et al.: Anti-Tumor Effect of Pectolinarigenin in Nasopharyngeal Carcinoma}

Subcutaneous xenograft mice model andimmunohistochemical (IHC) staining

NPC subcutaneous xenograft mice model was established by inoculating $0.2 \mathrm{ml} \mathrm{C666-1}$ cell suspension at the density of $1 \times 10^{5} / \mathrm{ml}$ in the right armpit of nude mice. The tumor growth were monitored and all reached the size of $5 \mathrm{~mm}$ at 2 weeks. The tumor volume was calculated as length $\mathrm{x}$ width $\mathrm{x}$ width $/ 2$. The mice were randomly divided into 5 groups, which were given $20 \mathrm{mg} / \mathrm{kg}, 40 \mathrm{mg} / \mathrm{kg}$ and $80 \mathrm{mg} / \mathrm{kg}$ pectolinarigenin, DMSO (negative control) and $3 \mathrm{mg} / \mathrm{kg}$ cisplatin (DDP, positive control) by intraperitoneal injection once a day for 3 days, which was stopped for 4 days as a therapeutic cycle. After 4 cycles, the mice were all sacrificed and the tumor were removed. IHC staining of cleaved caspase 3, Bax and BclXL/S (Cell Signaling, USA) for tumor tissue was conducted. The staining was detected by DAB method and the results were analyzed by Image Pro Plus 6.0. All the experiments were carried in triplicates. The toxicity of pectolinarigenin on heart, liver and kidney tissue were also evaluated by pathology. Blood sample was collected and haemoglobin, RBC and WBC count were detected. This study was approved by SMMU Ethics Committee and carried out in accordance with NIH guidelines for the care and use of laboratory animals.

\section{Western blot}

The protein concentration of cell or tumor lysate was quantified using a BCA protein assay kit (Beyotime, China). Equal amounts of protein were separated using SDS-PAGE and transferred to nitrocellulose membranes. The western blotting analysis was conducted using primary anti-human antibodies recognizing cleaved caspase 3 and 9, Bax and Bcl-XL/S (Cell Signaling, USA). The secondary antibodies were incubated with the membranes at room temperature for $1 \mathrm{~h}$. The immunocomplexes were visualized using a horseradish peroxidase-conjugated antibody, followed by a chemoluminescence reagent (Millipore, USA) and detected on photographic film.

\section{Statistical analysis}

The continuous and categorical data were expressed as the mean \pm standard deviation (SD) and percentage (\%), respectively. Significant differences between the two groups were determined by Student's t-test and chi-square test. A value of $\mathrm{P}<0.05$ was considered to be statistically significant.

\section{Results}

Pectolinarigenin inhibited cell proliferation and colony formation in C666-1 cells

We tested the inhibitory effects of pectolinarigenin on C666-1 cells via the CCK-8 assay. C666- 1 cells were incubated with pectolinarigenin (ranging from 2 to $512 \mu \mathrm{g} / \mathrm{ml}$ ) for $24 \mathrm{~h}$ and $48 \mathrm{~h}$, respectively. As shown in Fig. 2A, compared with the cells treated with DMSO,

Fig. 2. Pectolinarigenin inhibited cell viability $(A, B)$ and colony formation (C) of C666-1 cells. The effect of pectolinarigenin on cell viability was measured by CCK-8 assay. C666-1 cells were treated with pectolinarigenin for 24 and $48 \mathrm{~h}$. Pectolinarigenin significantly inhibited cell viability of C666-1 cells in a dose- and time-dependent manner.

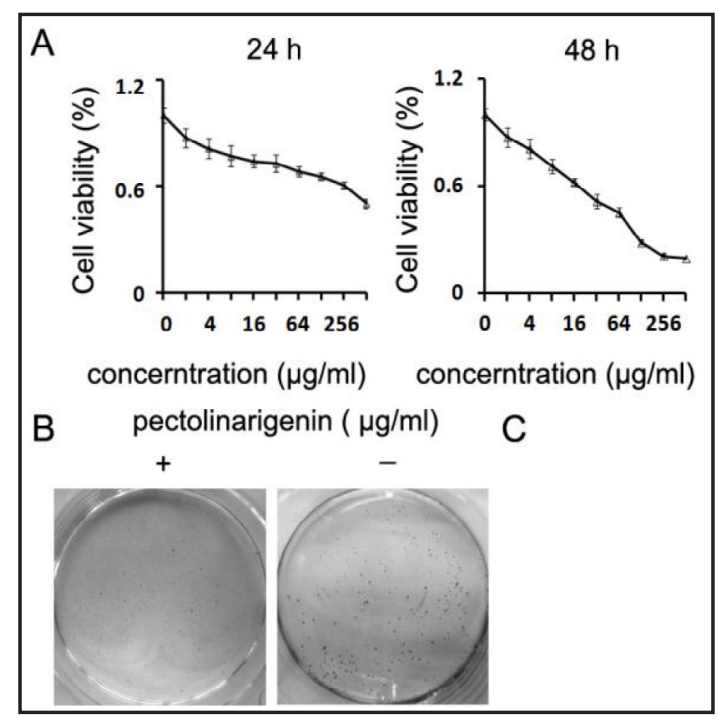


a marked dose and time dependent antiproliferative activity was observed in C666-1 cells treated with pectolinarigenin for $24 \mathrm{~h}$ and $48 \mathrm{~h}$, respectively. These data demonstrated that pectolinarigenin had a dramatic inhibitory effect on the proliferation of C666-1 cells. A colony formation assay was used to detect the ability of C666-1 cells to form colonies in 6-well plates after treatment with pectolinarigenin or DMSO for 7 days. As shown in Fig. 2B and C, colony formation of C666-1 cells was reduced by nearly $90 \%$ at the concentration $40 \mu \mathrm{g} /$ $\mathrm{ml}$ of pectolinarigenin. These data indicate that pectolinarigenin showed a similar level of proliferation inhibition in C666-1 cells.

Pectolinarigenin induced mitochondrialrelated apoptosis

To determine whether the growthinhibition effect exerted on C666-1 cells was also accompanied with apoptosis, the C6661 cells were treated with pectolinarigenin for $24 \mathrm{~h}$, and the apoptotic cells were detected by flow cytometer. As observed in Fig. 3A, these cells also showed an increase in the percentage of apoptotic cells. To further assess the effects of pectolinarigenin on the mitochondrial apoptotic pathway, mitochondrial membrane potential was evaluated by determination of fluorochrome dye JC-1. The data (Fig. 3B) obtained from flow cytometry demonstrate that JC-1 was accumulated in control cells treated with DMSO, indicating a high membrane potential, while JC-1 was poorly accumulated in pectolinarigenin-treated cells, indicating the disruption of $\Delta \Psi \mathrm{m}$.

Pectolinarigenin activated caspase 3 and 9 and the accumulation of ROS in promoting cell apoptosis

To determine whether treatment of cells with pectolinarigenin is associated with the generation of ROS, the intracellular ROS level in C666-1 cells was measured using the fluorescent probe DCFH/DA. In comparison, a significant increase was observed in the intensity of DCF fluorescence in pectolinarigenin treated C666-1 cells compared to that exposed to DMSO. Figure 4 showed that the fluorescence intensity of DCF in the pectolinarigenin group

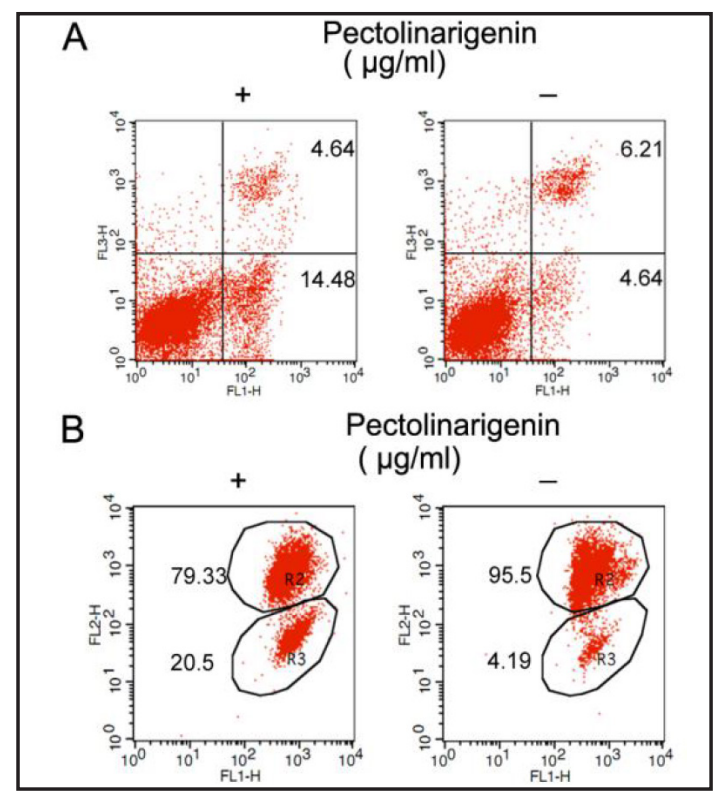

Fig. 3. Pectolinarigenin induced cell apoptosis in C666-1 cells (A) and disrupted the mitochondria membrane potential (B).

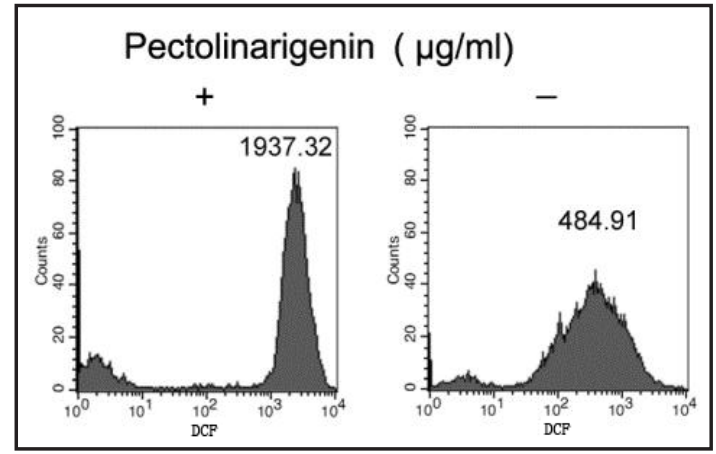

Fig. 4. Pectolinarigenin markedly increased the generation of ROS in C666-1 cells.

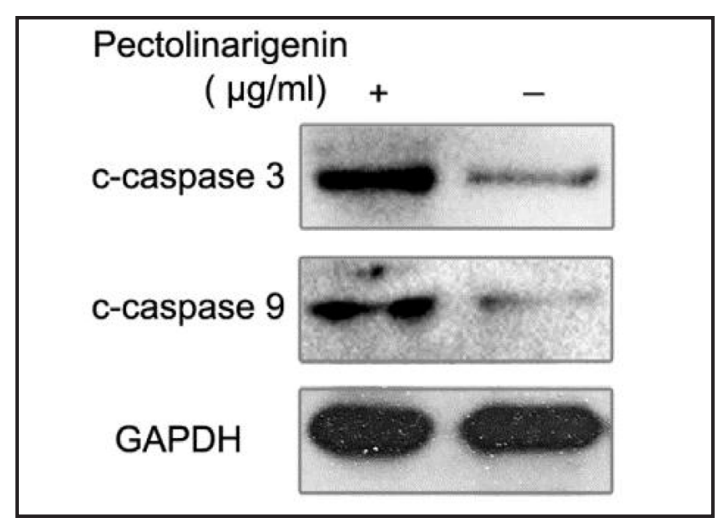

Fig. 5. Western blot detected the significantly increased level of cleavage of caspase 3 and 9 in C666-1 cells after pectolinarigenin treatment for $24 \mathrm{~h}$.

\section{KARGER}




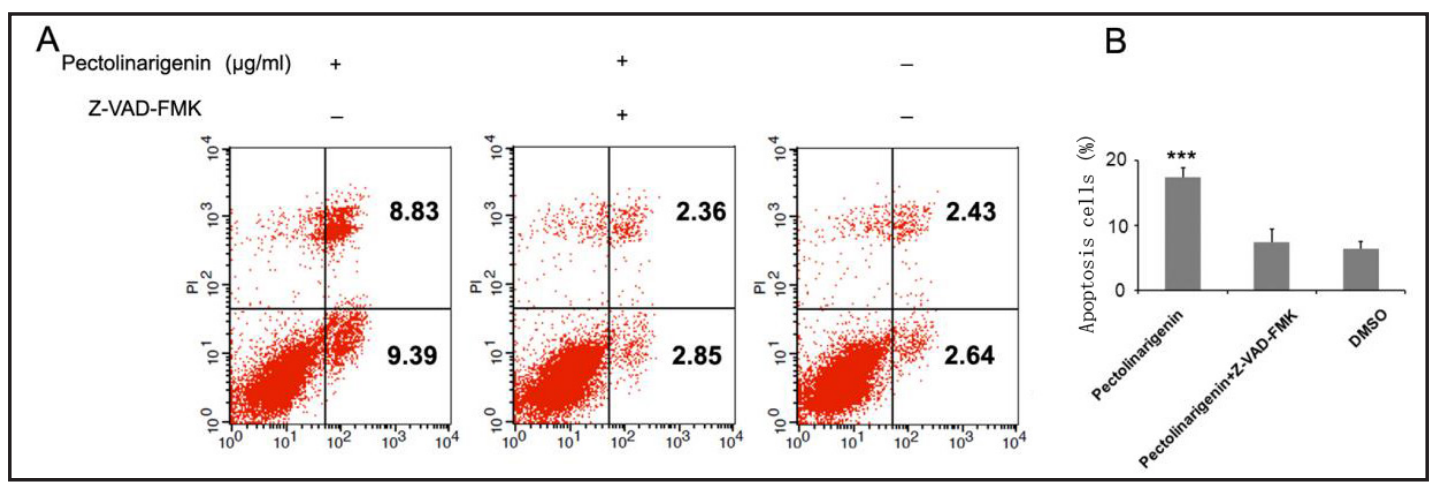

Fig. 6. Caspase inhibitor of z-VAD-fmk could greatly but not completely abolished the effect of pectolinarigenin on cell apoptosis (A, B).

Fig. 7. Treatment of pectolinarigenin decreased cell migration, shown in transwell assay (A) and wound healing assay (B).

was much higher than that in the control group. Exposure of cells to pectolinarigenin within $24 \mathrm{~h}$ instantly enhanced the intracellular ROS level.

Since caspases are known to play critical roles in the initiation and maintenance of apoptosis, activation of caspases was used to explore the mechanism of pectolinarigenin-induced apoptosis in C666-1 cells. To further examine the involvement of $\Delta \Psi \mathrm{m}$ and ROS in apoptosis induction by pectolinarigenin, we examined the activities of caspase 3 and 9, as

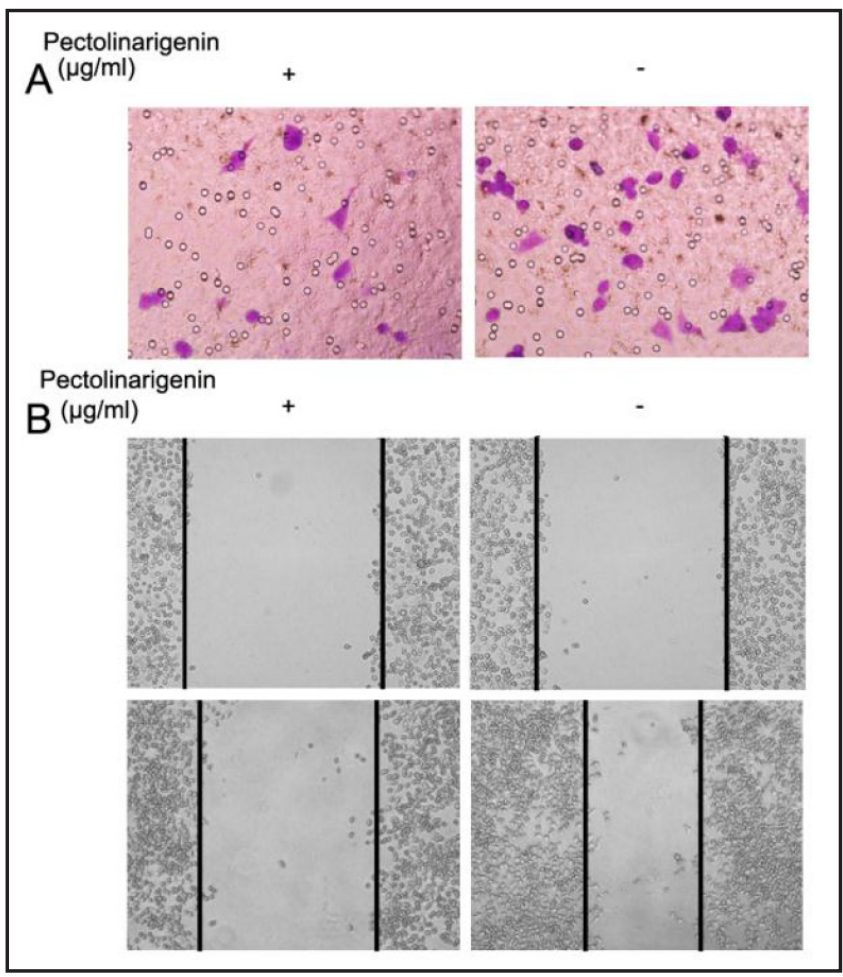

shown in Fig. 5. Western blotting data showed that the expression levels of cleaved caspase 3 (17kDa proteolytic fragments) and cleaved caspase 9 (37kDa proteolytic fragments) were elevated after pectolinarigenin treatment for $24 \mathrm{~h}$ in C666-1 cells. The results suggest that $\Delta \Psi \mathrm{m}$ and ROS may be the upstream factor of caspase activation and may play an important role in pectolinarigenin-induced cytotoxicity in C666-1 cells. To further confirm whether pectolinarigenin induced cell apoptotic death was through caspase activation, a general caspase inhibitor, z-VAD-fmk, was used. The caspase inhibitor (z-VAD-fmk) significantly, but not entirely, prevented an increase in the proportion of apoptotic cells (Fig. 6A-B).

\section{Pectolinarigenindecreased the migration of C666-1 cells and suppressed tumor growth in} vivo

The transwell assay was used to validate the effects of pectolinarigenin on migration of C666- 1 cells. The numbers of cells treated with pectolinarigenin that migrated to the lower surfaces of the transwells were reduced in comparison to the cells treated with DMSO (Fig. 7A). A scratch migration assay was also performed to assess the migration of C666-1 cells. The 


\section{Cellular Physiology Cell Physiol Biochem 2016;39:1795-1803

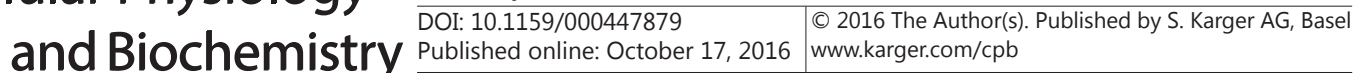 \\ Wang et al.: Anti-Tumor Effect of Pectolinarigenin in Nasopharyngeal Carcinoma}

Table 1. Inhibition effect of pectolinarigenin on xenograft tumor growth in human NPC C666-1 nude mice. ** $\mathrm{P}<0.01$ vs Control group by student t-test

\begin{tabular}{ccccc}
\hline $\begin{array}{c}\text { Group } \\
(\mathrm{n}=6, \overline{\mathrm{x}} \pm \mathrm{s})\end{array}$ & dose, $\mathrm{mg} \cdot \mathrm{kg}^{-1}$ & $\begin{array}{c}\text { Mean tumor volume, } \\
\mathrm{V} / \mathrm{mm}^{3}\end{array}$ & $\begin{array}{c}\text { Mean tumor weight, } \\
\mathrm{m} / \mathrm{mg}\end{array}$ & $\begin{array}{c}\text { Inhibitory } \\
\text { rate, } \%\end{array}$ \\
\hline Control & - & $1980.22 \pm 155.71$ & $1099.67 \pm 108.09$ & - \\
pectolinarigenin & 20 & $1512.71 \pm 139.44^{* *}$ & $848.83 \pm 67.72^{* *}$ & 22.81 \\
& 40 & $1143.20 \pm 103.62^{* *}$ & $631.05 \pm 64.15^{* *}$ & 42.61 \\
& 80 & $740.22 \pm 84.10^{* *}$ & $412.07 \pm 54.91^{* *}$ & 62.53 \\
DDP & 3 & $804.47 \pm 77.91^{* *}$ & $447.67 \pm 52.27^{* *}$ & 59.29 \\
\hline
\end{tabular}

Table 2. Blood sample from the mice model in negative control and $80 \mathrm{mg} / \mathrm{Kg} / \mathrm{d}$ pectolinarigenin group were collected and no significant difference was found on the white blood cell count, hemogblobulin and red blood cell count (all P > 0.05). * Student t-test

\begin{tabular}{|c|c|c|c|c|}
\hline & \multicolumn{2}{|c|}{ Negative control $(n=6)$} & \multicolumn{2}{|c|}{$80 \mathrm{mg} / \mathrm{Kg} / \mathrm{d}$ Pectolinarigenin $(n=6)$} \\
\hline & Before treatment & After treatment & Before treatment & After treatment \\
\hline $\begin{array}{l}\text { White blood cell } \\
\text { count, } \times 10^{9} / \mathrm{L}\end{array}$ & $11.1 \pm 3.7$ & $14.7 \pm 2.0$ & $8.1 \pm 1.2$ & $12.5 \pm 3.0$ \\
\hline Hemoglobulin, g/L & $154.7 \pm 31.2$ & $147.3 \pm 15.2$ & $145.0 \pm 10.5$ & $144.7 \pm 8.7$ \\
\hline $\begin{array}{l}\text { Red blood cell count, } \\
\times 10^{12} / \mathrm{L}\end{array}$ & $9.7 \pm 2.1$ & $9.1 \pm 1.2$ & $9.1 \pm 0.8$ & $8.9 \pm 0.9$ \\
\hline
\end{tabular}

cells treated with pectolinarigenin migrated into the wound with a significantly decreased distance between the edges compared to the control group in C666-1 cells (Fig. 7B). The NOC subcutaneous xenograft mice model was successfully established. Administration of pectolinarigenin could reduce the tumor growth in a dosage-dependent manner (Table 1) using DDP as a positive control, and no obvious cytotoxic effect was observed in heart, liver, kidney and blood sample (Table 2), indicating that pectolinarigenin may be a safe and promising therapy for treating NPC. IHC of tumor tissue also detected the upregulation of Bax and cleaved caspase 3 but downregulation of $\mathrm{Bcl}-\mathrm{XL} / \mathrm{S}$, which were consistent with in vitro findings.

\section{Discussion}

NPC is one of the most common head and neck cancer in southern China and South East Asia. The current treatment strategy in non-metastatic NPC is a course of radical radiotherapy in early stage disease, and concurrent chemo-radiotherapy in locally advanced stage [14]. Cisplatin and paclitaxel have been two of the most active cytotoxic chemotherapeutic drugs in NPC [15]. Despite an aggressive approach combining both chemotherapy and radiotherapy, about $25-30 \%$ of patients still fail with local recurrence and/or distant metastases. The prognosis for patients with metastatic disease is poor [16]. Therefore, new therapeutic strategies need to be explored in order to further improve the treatment outcome. The current study demonstrated that pectolinarigenin has cytotoxic effects and induces apoptosis of the C666-1 cells. Compared with CCK-8 and colony formation assays, pectolinarigenin had a dramatic inhibitory effect on the proliferation of C666-1 cells (Fig. 2A). Treatment with pectolinarigenin induced C666-1 cell apoptosis, as demonstrated by flow cytometry. The flow cytometric results indicated that pectolinarigenin sinulariolide induced both early and late apoptosis (Fig. 3A).

In the present study, we showed that pectolinarigenin can initiate the intrinsic apoptotic mechanism via downregulation of $\Delta \Psi \mathrm{m}$ and upregulation of ROS in C666-1 


\section{Cellular Physiology Cell Physiol Biochem 2016;39:1795-1803 \begin{tabular}{ll|l} 
DOI: 10.1159/000447879 & $\begin{array}{l}\text { O 2016 The Author(s). Published by S. Karger AG, Basel } \\
\text { www.karger.com/cpb }\end{array}$
\end{tabular} \\ Wang et al.: Anti-Tumor Effect of Pectolinarigenin in Nasopharyngeal Carcinoma}

cells by flow cytometry analysis. Numerous investigations have found that ROS are highly reactive molecules that originate mainly from the mitochondrial electron transport chain, and damaged mitochondria stimulate increased ROS production [17]. Indeed, we found that pectolinarigenin caused some changes in mitochondrial membrane potential and enhanced the level of ROS in C666-1cells. The results suggest that ROS may be the upstream factor of caspase activation and may play an important role in pectolinarigenin-induced cytotoxicity in C666-1 cells. ROS are produced by all aerobic cells to regulate cell development, growth, survival and death. ROS normally exists in balance with biochemical antioxidants in all aerobic cells [18-20]. When this critical balance is disrupted by excess ROS production and/or antioxidant depletion, oxidative stress may come to exist [21, 22]. ROS exerts their damaging effects by modification of intracellular or extracellular macromolecules, hyperor hypo-functionality of the signaling pathways, and finally leading to exert pathological effects or alter their physiological action. Therefore, ROS has been an important target for developing anti-tumor drugs.

Our present study revealed that pectolinarigenin can induce apoptosis of C6661 cells through the activation of mitochondria-related apoptotic pathway. We further demonstrated that the involvements of caspase 3 and caspase 9 were demonstrated in the previous section, and these suggested that mitochondrial-related apoptotic pathway plays a critical role in the pectolinarigenin-induced cell apoptosis. When C666-1 cells were treated with pectolinarigenin, caspase 3 and 9 were cleaved. Furthermore, the caspase inhibitor (z-VADfmk) significantly prevented an increased proportion of apoptotic cells. Additionally, in our study migratory characteristics were explored in C666-1 cells after pectolinarigenin treated, and it was found that the migration of C666-1 cells was significantly reduced. Thus, findings in our experiments together with others hinted at the answer that a correlation was found between pectolinarigenin and C666-1 cells growth and migration. The above observation also suggested that pectolinarigenin can inhibit the proliferation in vitro. Although further studies are needed, our results pointed out how pectolinarigenin can be considered as a potential new pharmacological tool to reduce the growth of NPC.

In summary, these results demonstrated pectolinarigenin is capable of inducing C666-1 cell apoptosis via both mitochondrial-related apoptotic pathway and ROS induced apoptotic pathway. Further study is indicated to determine the therapeutic potential of pectolinarigenin in treating patients with NPC in future.

\section{Acknowledgements}

This work was supported by the Key Basic Research of the Shanghai Committee of Science and Technology, China (12JC1411100).

\section{Disclosure Statement}

The authors declare there is no conflict of interest.

\section{References}

1 Lee AW, Lin JC, Ng WT: Current management of nasopharyngeal cancer. Semin Radiat Oncol 2012;22:233244.

2 Baujat B, Audry H, Bourhis J, Chan AT, Onat H, Chua DT, Kwong DL, Al-Sarraf M, Chi KH, Hareyama M, Leung SF, Thephamongkhol K, Pignon JP: Chemotherapy as an adjunct to radiotherapy in locally advanced nasopharyngeal carcinoma. Cochrane Database Syst Rev 2006;4:CD004329. 


\section{Cellular Physiology Cell Physiol Biochem 2016;39:1795-1803 \begin{tabular}{l|l|l|}
\hline DOI: 10.1159/000447879 & $\begin{array}{l}\text { C) 2016 The Author(s). Published by S. Karger AG, Basel } \\
\text { www.karger.com/cpb }\end{array}$ \\
\hline
\end{tabular} \\ Wang et al.: Anti-Tumor Effect of Pectolinarigenin in Nasopharyngeal Carcinoma}

3 Lowe SW, Lin AW: Apoptosis in cancer. Carcinogenesis 2000;21:485-495.

4 Qi X, Li J, Zhou C, Lv C, Tian M: MiR-142-3p Suppresses SOCS6 Expression and Promotes Cell Proliferation in Nasopharyngeal Carcinoma. Cell Physiol Biochem 2015;36:1743-1752.

5 Zhang SX, Qiu QH, Chen WB, Liang CH, Huang B: Celecoxib enhances radiosensitivity via induction of G(2)-M phase arrest and apoptosis in nasopharyngeal carcinoma. Cell Physiol Biochem 2014;33:14841497.

6 Xie M, Yi X, Wang R, Wang L, He G, Zhu M, Qi C, Liu Y, Ye Y, Tan S, Tang A: 14-Thienyl methylene matrine (YYJ18), the derivative from matrine, induces apoptosis of human nasopharyngeal carcinoma cells by targeting MAPK and PI3K/Akt pathways in vitro. Cell Physiol Biochem 2014;33:1475-1483.

7 Chandra J, Samali A, Orrenius S: Triggering and modulation of apoptosis by oxidative stress. Free Radic Biol Med 2000;29:323-333.

8 Carmody RJ, Cotter TG: Signalling apoptosis: a radical approach. Redox Rep 2001;6:77-90.

9 Lim H, Son KH, Chang HW, Bae K, Kang SS, Kim HP: Anti-inflammatory activity of pectolinarigenin and pectolinarin isolated from Cirsium chanroenicum. Biol Pharm Bull 2008;31:2063-2067.

10 Muthu C, Reegan AD, Kingsley S, Ignacimuthu S: Larvicidal activity of pectolinaringenin from Clerodendrum phlomidis L. against Culex quinquefasciatus Say and Aedes aegypti L. (Diptera: Culicidae). Parasitol Res 2012;111:1059-1065.

11 Sujatha P, Sreekanth G, Khasim S, Adavi Rao BV, Ravi Kumar B, Appa Rao AV: Flavonoids of Dikamali: A phytochemical reinvestigation. Nat Prod Res 2013;27:1930-1932.

12 Tsang J, Lee VH, Kwong DL: Novel therapy for nasopharyngeal carcinoma--where are we. Oral Oncol 2014;50:798-801.

13 Yoo YM, Nam JH, Kim MY, Choi J, Park HJ: Pectolinarin and Pectolinarigenin of Cirsium setidens Prevent the Hepatic Injury in Rats Caused by D-Galactosamine via an Antioxidant Mechanism. Biol Pharm Bull 2008;31:760-764.

14 Chan AT, Teo PM, Johnson PJ: Nasopharyngeal cancer. Cancer Treat Res 2003;114:275-293.

15 Qu S, Liang ZG, Zhu XD: Advances and challenges in intensity-modulated radiotherapy for nasopharyngeal carcinoma. Asian Pac J Cancer Prev 2015;16:1687-1692.

16 Hui EP, Leung SF, Au JS, Zee B, Tung S, Chua D, Sze WM, Law CK, Leung TW, Chan AT: Lung metastasis alone in nasopharyngeal carcinoma: a relatively favorable prognostic group. A study by the Hong Kong Nasopharyngeal Carcinoma Study Group. Cancer 2004;101:300-306.

17 Verschoor ML, Wilson LA, Singh G: Mechanisms associated with mitochondrial-generated reactive oxygen species in cancer. Can J Physiol Pharmacol 2010;88:204-219.

18 Formentini L, Sanchez-Arago M, Sanchez-Cenizo L, Cuezva JM: The mitochondrial ATPase inhibitory factor 1 triggers a ROS-mediated retrograde prosurvival and proliferative response. Mol Cell 2012;45:731-742.

19 Sanchez-Cenizo L, Formentini L, Aldea M, Ortega AD, Garcia-Huerta P, Sanchez-Arago M, Cuezva JM: Upregulation of the ATPase inhibitory factor 1 (IF1) of the mitochondrial H+-ATP synthase in human tumors mediates the metabolic shift of cancer cells to a Warburg phenotype. J Biol Chem 2010;285:25308-25313.

20 Lee PJ, Shin I, Seo SY, Kim H, Kim HP: Upregulation of both heme oxygenase-1 and ATPase inhibitory factor 1 renders tumoricidal activity by synthetic flavonoids via depleting cellular ATP. Bioorg Med Chem Lett 2014;24:4845-4849.

21 Lenaz G: Mitochondria and reactive oxygen species. Which role in physiology and pathology? Adv Exp Med Biol 2012;942:93-136.

22 Kadenbach B: Introduction to mitochondrial oxidative phosphorylation. Adv Exp Med Biol 2012;748:1-11. 